\title{
THE PRINCIPALS' EFFORTS IN FACILITATING THE FREEDOM TO LEARN BY ENHANCING COMMUNITY PARTICIPATION IN INDONESIA
}

\author{
Maisyaroh $^{1 *}$, Juharyanto ${ }^{1}$, Ibrahim Bafadal ${ }^{1}$, Bambang Budi Wiyono ${ }^{1}$, Nova Syafira Ariyanti ${ }^{1}$, \\ Maulana Amirul Adha ${ }^{1}$, Muhammad Imran Qureshi ${ }^{2}$ \\ ${ }^{1}$ Universitas Negeri Malang, Indonesia \\ ${ }^{2}$ Universiti Teknikal Malaysia Melaka, Malaysia \\ *e-mail: maisyaroh.fip@um.ac.id
}

\begin{abstract}
The latest 'freedom to learn' policy, issued by the Minister of Education and Culture of the Republic of Indonesia, must be implemented by educational institutions at various levels. The principals played significant roles such as community empowerment to utilize all resources in the schools to support the policy. The research aimed to describe the principals' efforts in improving community participation in the school and to describe the social involvement in facilitating the freedom to learn at schools. This study employed a qualitative approach with a multi-case research design, and it was conducted in Indonesia, particularly in Tana Tidung Regency in North Kalimantan, Bondowoso Regency in East Java, and Malang City in East Java. The data collection techniques included in-depth interviews and document studies, and to validate the data used a credibility technique. The data validation through the credibility technique was carried out by conducting triangulation, checking members, and improving the persistence and adequacy of reference materials. The cross-case data analysis in this study applied a constant comparative method. The analysis was conducted in all three cases resulted in the provisional findings, continued by data comparison that would later be found by the three cases. The results of this research were the principals' efforts in enhancing community participation through cooperation with several related parties. The principals were regarded as role models in supporting the 'freedom to learn' policy and building cooperation with related partners. The kind of community participation varied based on the uniqueness of each region.
\end{abstract}

\section{Keywords: community participation, principals, freedom to learn.}

\section{UPAYA KEPALA SEKOLAH DALAM MEMFASILITASI KEMERDEKAAN BELAJAR DI SEKOLAH MELALUI PENINGKATAN PERAN SERTA MASYARAKAT DI INDONESIA}

\begin{abstract}
Abstrak: Kebijakan merdeka belajar yang diputuskan oleh menteri pendidikan dan kebudayaan Republik Indonesia, menjadi kebijakan baru yang harus dilaksanakan oleh lembaga sekolah dari berbagai jenjang. Kepala sekolah dihadapkan pada perannya dalam mendayagunakan segala sumber daya yang ada di sekolah untuk mendukung kebijakan tersebut termasuk pemberdayaan peran serta masyarakat di sekolah. Tujuan penelitian ini untuk mendeskripsikan upaya kepala sekolah dalam meningkatkan peran serta masyarakat di sekolah dan mendeskripsikan bentuk peran serta masyarakat dalam memfasilitasi kemerdekaan belajar di sekolah. Penelitian ini menggunakan pendekatan kualitatif dengan rancangan penelitian multikasus. Penelitian dilakukan di Indonesia ya Kabupaten Tana Tidung Kalimantan Utara, Kabupaten Bondowoso Jawa Timur dan Kota Malang Jawa Timur. Teknik dalam pengambilan data yakni wawancara mendalam dan studi dokumentasi. Pemeriksaan keabsahan data menggunakan kredibilitas. Pengecekan keabsahan data melalui kredibilitas dilakukan dengan triangulasi, pengecekan anggota, peningkatan ketekunan dan kecukupan bahan referensi. Analisis data lintas kasus dalam penelitian ini menggunakan analisis komparatif konstan. Analisis yang dilakukan pada ketiga kasus tersebut menghasilkan temuan sementara, yang kemudian dilakukan perbandingan data yang nantinya akan ditemukan oleh ketiga kasus tersebut. Hasil dari penelitian ini yakni upaya kepala sekolah dalam meningkatkan peran serta masyarakat melalui kerja sama dengan beberapa pihak terkait. Kepala sekolah sebagai role model dalam kebijakan merdeka belajar, sekaligus turut membangun kerja sama dengan mitra-mitra terkait. Bentuk peran serta masyarakat berbeda sesuai dengan keunikan daerah masing-masing.
\end{abstract}

Kata Kunci: peran serta masyarakat, kepala sekolah, merdeka belajar. 


\section{INTRODUCTION}

The existence of the school as a formal organization in the educational process, has the important thing to build a partner with several parties. In building partners, schools require involvement from various external parties of the school. This makes community participation has an influence in building partners (Blechman, Davidson, \& Kelly, 2017; Sofoluwe \& Akinsolu, 2015). The involvement is inseparable from the managerial role of the principal, where there are five competencies of the principal, one of which states that the principal must have social competence (Aas \& Paulsen, 2019; Hutton, 2017). The social competence is implemented by the principal in building the school's image in improving community participation.

Based on several aspects, skilled in working with others means being able to build cooperation with several related parties. As opinions (Mapp \& Kuttner, 2013; Šteh \& Kalin, 2011) explained that to build a partner there needs to be communication between the school and the community and the environment around the school. Especially the principal needs to communicate educational activities and ask for problem solving. Furthermore, aspects of the ability to participate in social activities must also be owned by the principal, social activities among schools are activities and responsibilities to increase public and parental trust in the school (Falahah \& Rosmala, 2012; Sari \& Gökdağ, 2017). So that this social activity must continue to run. The next aspect is to have social sensitivity, in this aspect the principal is required to have a sensibility in the community and environment (Barnett \& McCormick, 2012; Dinham \& Crowther, 2011). This can be formed if the principal is able to communicate with the community repeatedly. Social sensitivity has an important role in the academic activities of the school, because the community is not disturbed by the activities carried out by the school (Koc \& Turan, 2018; Yang, Chen, \& Wang, 2015).

The learning independency policy, which was decided by the minister of education and culture of the Republic of Indonesia, became a new policy that must be implemented by school institutions from various levels (Abidah, Hidaayatullaah, Simamora, Fehabutar, \& Mutakinati, 2020; Baro'ah, 2020). There are four aspects that must be understood and implemented by education implementers at the school institution level. First, a change in policy direction regarding the National-Based School Examination (USBN) which will be transformed into a more comprehensive competency assessment, namely assignments and portfolios, which will be moved in schools. Second, the National Examination will be last held in 2020, and the following year will be replaced with a minimum competency assessment and character survey consisting of reasoning ability using language (literacy), reasoning ability using mathematics (numeration) and strengthening character education. The third is to simplify the preparation of the Lesson plan (RPP) where teachers are given the flexibility to select, arrange, use and develop lesson plan format that contains about learning objectives, learning activities, and assessments. The fourth aspect is the zoning system in the Acceptance of New Learner as a form of accommodation against inequality of access and quality in various regions, where the education office in the region is authorized to determine the final proportion and establish the zoning area (Abidah et al., 2020; Hendri, 2020).

The learning independency policy is a decision issued by the minister of education and culture of the Republic of Indonesia in 2020. This makes educational institutions have to change the working patterns of the school. The meaning of independent self-learning does not eliminate the essence of independency learning in accordance with the wishes of learners, but rather still refers to the rules that have been made (Jahari, 2020). The decision reaped many pros and cons, especially from experts or education experts, not only that the field such as principals and teachers also issued many ideas of pros and cons related to the policy. In the guidebook related to independency learning there is a statement that schools can build partners with various institutions other than education. That is, schools can partner with the industrial world as well as others. Similarly, the managerial ability that must be possessed by the principal, to increase public trust needs to have partners with other parties.

As a manager, the principal needs to see the interrelation of educational elements as a system (Chan, 2014; Rivai \& Murni, 2009), including being able to reconstruct how to think about different types of relationships and 
how organizations change. In the context of the digital age, where learning resources have been presented so openly, the implications of learning that provide independencies of learning need to be enforced and implemented. As managers and leaders, principals need to have excellent leadership skills, which are effective for change (Akkary, 2013; Kin, Kareem, Nordin, \& Bing, 2017). The importance of the change mindset and the implementation of managerial and leadership roles in facilitating the implementation of learning independency policy based on the digital era must be emphasized. The principal must have the ability to work in the areas of school management digitally.

There are often different formulations of school excellence in each district. This is normal because each region has different carrying capacity. Of course, the concept of independencies of learning, school excellence, and the roles and management models of the principal will look different, in accordance with the differences typical of their respective regions. This research was conducted in three areas in Indonesia with specifications of disadvantaged areas represented by Tana Tidung Regency of North Kalimantan, the developing area of Bondowoso Regency of East Java and the advance regions are represented by Malang City of East Java. The purpose of this research is to describe the efforts of the principal in improving the participation of the community in the school, and to describe the form of community participation in facilitating the independence of learning in schools.

\section{METHOD}

This research uses qualitative approach. The informants in this study were 36 informants consisting of 9 principals and 27 teachers. The location of this study was located in three regencies or cities from two different provinces in Indonesia, namely Tana Tidung Regency of North Kalimantan Province, and Bondowoso Regency and Malang City of East Java Province. The location of the research is an area that is eligible for this research, because it is considered to have the characteristics needed by researchers in the efforts to collect relevant data. Each district took 3 excellent schools, of which 1 principal and 3 teachers were taken as informants in this study. Research location in Tana Tidung Regency of North Kalimantan, namely SMPN ${ }^{1}$ Terpadu Unggulan $^{2} 1$ Tana Tidung, SMPN Terpadu Unggulan 2 Tana Tidung and $\mathrm{SDN}^{3}$ Terpadu Unggulan 2 Tana Tidung. For research locations in Bondowoso Regency of East Java consists of SDN Kotakulon 1 Bondowoso, SDN Dabasah 1 Bondowoso, and SMPN 1 Bondowoso. And research in Malang City of East Java, namely SDN Tunjungsekar 1 Malang, SDN Percobaan 1 Malang, and SMPN 10 Malang. The researchers have received permission from the research committee and the schools to collect the data and report the name of the school in this article.

Data collection is done with 2 techniques, namely in-depth interviews and documentation studies. This is done because it is blocked by the Covid-19 pandemic so that it cannot observe directly the behavior related to the theme of research. In-depth interviews are conducted by researchers in order to get accurate and specific information related to the theme of research. Meanwhile, documentation studies were conducted as supporting evidence of the interview results. Researchers also triangulated the source. Source triangulation is done so that data obtained from one source with another source is the same.

Cross-case data analysis in this study used constant comparative analysis. Analysis conducted in all three cases resulted in provisional findings, which then carried out a comparison of data that would later be found by the three cases. While checking the validity of the data using credibility. This is done by researchers to account for the data that has been obtained from informants. Checking the validity of data through credibility is carried out by triangulation, checking members, increasing the persistence and adequacy of reference materials. Triangulation is done by researchers with triangulation of sources, related sources, namely the results of interviews and documentation studies. As for checking members, researchers conducted by relaying the results of research to the relevant informants. For the validity of data in improving the persistence of researchers in

\footnotetext{
${ }^{1}$ SMPN is public secondary school

${ }^{2}$ Sekolah terpadu unggulan (flagship integrated school) is schools that are organized in a single complex and are managed in an integrated manner, from the aspects of curriculum, learning, teachers, facilities, management, and evaluation, so that they become effective and quality schools.

${ }^{3} \mathrm{SDN}$ is public elementary school
} 
order to get more specific research results and convey the results of research in detail. Next, the researchers used the adequacy of reference materials, because to support the results of this study needed related theories. Multi-case analysis techniques were used in this study, this was done due to the background of each different research location.

\section{RESULTS AND DISCUSSION Results}

The results of research in Tana Tidung Regency of North Kalimantan, Bondowoso Regency of East Java and Malang City of East Java, related to the principal's efforts to increase community participation which got positive results. Meaning, in these three areas there are similarities to increase the participation of the community, especially with the existence of this learning independency policy. However, the way schools are in each regencies / cities is different. The differences are as in Table 1.

In this study, the principal's efforts through community participation in facilitating independencies of learning are uniqueness and peculiarities of each region. In Tana Tidung Regency, North Kalimantan Province, where access to schools or other areas must go down the river using water transportation, one form of community participation that is not in other

Table 1. Findings across Cases of The Principal's Efforts in Improving Community Participation

\begin{tabular}{|c|c|c|c|}
\hline \multirow{2}{*}{$\begin{array}{l}\text { The Principal's } \\
\text { Efforts }\end{array}$} & \multicolumn{3}{|l|}{ Cross-Case Findings } \\
\hline & Malang City & Bondowoso Regency & Tana Tidung Regency \\
\hline \multirow{9}{*}{$\begin{array}{l}\text { The managerial } \\
\text { role of the } \\
\text { principal through } \\
\text { the participation } \\
\text { of the community } \\
\text { in facilitating the } \\
\text { independency } \\
\text { learning }\end{array}$} & $\begin{array}{l}\text { Universities: } \\
\text { Apprenticeships, } \\
\text { curriculum reviews, } \\
\text { learning media innovations }\end{array}$ & $\begin{array}{l}\text { Kelurahan (village } \\
\text { government): check the } \\
\text { flicks in the bathtub }\end{array}$ & $\begin{array}{l}\text { Principal becomes role } \\
\text { model }\end{array}$ \\
\hline & $\begin{array}{l}\text { Partner schools: } \\
\text { Teacher becomes } \\
\text { Ceremony instructor }\end{array}$ & $\begin{array}{l}\text { Police: counseling of } \\
\text { students on a regular } \\
\text { basis }\end{array}$ & $\begin{array}{l}\text { Universities: Universitas } \\
\text { Negeri Malang and } \\
\text { Universitas Borneo }\end{array}$ \\
\hline & $\begin{array}{l}\text { National Narcotics Agency } \\
\text { (BNN): Drug-free coaching }\end{array}$ & $\begin{array}{l}\text { Sub-District Military } \\
\text { Command: Discipline }\end{array}$ & $\begin{array}{l}\text { Operational facilitator of } \\
\text { home visits }\end{array}$ \\
\hline & $\begin{array}{l}\text { Bank: Student savings, } \\
\text { honing soft skills }\end{array}$ & $\begin{array}{l}\text { The principal builds } \\
\text { activities with the } \\
\text { Industrial Business } \\
\text { World, banks, Tutoring } \\
\text { Institutions }\end{array}$ & $\begin{array}{l}\text { Facilitate free water } \\
\text { transportation for student } \\
\text { acces to school }\end{array}$ \\
\hline & $\begin{array}{l}\text { Public health office: } \\
\text { Healthy lifestyle }\end{array}$ & $\begin{array}{l}\text { Inspiration class from } \\
\text { alumni }\end{array}$ & $\begin{array}{l}\text { The role of parents in } \\
\text { classroom literacy }\end{array}$ \\
\hline & $\begin{array}{l}\text { Enviromental services and } \\
\text { cleanliness: Environmental } \\
\text { maintenance }\end{array}$ & Canteen honesty & $\begin{array}{l}\text { Education Office facilities } \\
\text { with the preparation of a } \\
\text { team of learning developers }\end{array}$ \\
\hline & $\begin{array}{l}\text { Non-Governmental } \\
\text { Organization of UMMI: } \\
\text { studying }\end{array}$ & $\begin{array}{l}\text { Parents contribute } \\
\text { voluntarily (budget, } \\
\text { support activities) }\end{array}$ & $\begin{array}{l}\text { Caregivers and ustadz in the } \\
\text { dormitory are involved in } \\
\text { improving the quality of free } \\
\text { learning }\end{array}$ \\
\hline & $\begin{array}{l}\text { Industries around the } \\
\text { school }\end{array}$ & $\begin{array}{l}\text { Outbond teachers and } \\
\text { student tours }\end{array}$ & $\begin{array}{l}\text { Village development helps } \\
\text { education near the mine }\end{array}$ \\
\hline & $\begin{array}{l}\text { Medical and health faculty } \\
\text { from the universities: } \\
\text { Dental care, school health } \\
\text { unit }\end{array}$ & $\begin{array}{l}\text { Parents/groups have sms } \\
\text { gateway }\end{array}$ & $\begin{array}{l}\text { Religious leaders in the } \\
\text { provision of religious } \\
\text { teachers }\end{array}$ \\
\hline
\end{tabular}


areas is the existence of water transportation facilities provided by one of the parents of the students, which can be ride by other students for free. This is inseparable from the efforts of the principal in seeking to increase the community's participation in the school as well as awareness from the community to participate in improving the quality of the school.

Meanwhile, in Bondowoso Regency, East Java Province, as a district that has just moved from poor district status began to utilize technology in an effort to increase community participation, such as the sms gateway for communication between schools and parents groups, in addition to the use of social media such as Whatsapp groups are also used to conduct communication with parents. In Malang City, East Java Province, which represents one of the most advanced cities in Indonesia, in addition to utilizing technology as an effort to increase community participation, schools also cooperate with many universities for the development of their main schools in terms of procuring apprenticeships as an exchange of information in terms of learning between those in schools and those taught on universities, curriculum reviews, and learning innovations in schools. In Malang city, the types of institutions that become school partners are more varied, including universities, partner schools, National Narcotics Agency (BNN), bank, public health office, environmental services and cleanliness office, alumni, parents, non-government organizations, stakeholders around the school, and industry around the school. Not only build cooperation with external parties of the school, but the principal is also a role model in this independency learning policy.

Based on the findings of the three regencies/cities in two different provinces above, there are differences in the efforts of the principal in increasing the participation of the community in order to facilitate the independency of learning. Different ways of implementing create uniqueness in each area. These three areas have different characteristics, as well as the participation of different communities. For the level of public concern in Tana Tidung Regency of North Kalimantan, Bondowoso Regency of East Java and Malang City of East Java is quite high. Because it is seen from the participation of the community, especially parents and active community leaders.

\section{Discussion \\ The Principal's Efforts to Increase Community Participation in Schools}

The existence of effectively functioning principals is a critical and organic factor (Intxausti, Joaristi, \& Lizasoain, 2016; Mulyani, Meirawan, \& Rahmadani, 2020) in the efforts to improve school quality. Other components such as facilities and infrastructure, curriculum, financing, public relations, student affairs, and school culture will not function optimally without the presence of an effective principal (Wiyono, 2018). The effective presence of the principal can ensure that quality education and school services can run to the maximum in accordance with the expectations of all internal and external parties of the school (Brinia, Zimianiti, \& Panagiotopoulos, 2014; Malakolunthu, McBeath, \& Swaffield, 2014). The existence of the principal as a critical factor needs to be functionally enforced to ensure the success of school quality improvement and school success (Lunenburg, 2010, 2011). The principal has a key role to play in implementing the school's programs as a representation of the ideals of the community as a whole (Juharyanto, Sultoni, Arifin, Bafadal, Nurabadi, \& Hardika (2020).

The principal, of course, needs to understand the important point of the independent policy of learning as a whole (Abidah et al., 2020; Yamin \& Syahrir, 2020). Because it will be related to the policy that will be taken by the principal as a leader in implementing the learning independency policy in schools. While as a manager, of course, with the learning independency policy, the principal was faced with his role in utilizing all resources in the school to support the policy including the empowerment of community participation in the school (Harsoyo, Astuti, \& Rahayu, 2019; Lindqvist \& Pettersson, 2019).

The different conditions of each school in the three districts are unique for each district or school. Because, in the concept of schoolbased management, the autonomy provided is in accordance with the needs of the school in an effort to formulation education policies at the school level (McEwan, 2015; Ulfatin, Mustiningsih, Sumarsono, \& Yunus, 2020). Any uniqueness or excellence of the school can be developed in the direction of the goal of 
learning independency policy. This includes the involvement of the community in supporting the policy of learning independency in schools. It requires the commitment of education policy makers at the regional level, principals, teachers, students, parents, community leaders, universities, industry, and various institutions that care about schools in optimizing learning activities in schools in accordance with the concept of learning independency policy (Çoruk, 2018; Rahabav, 2016).

The efforts of the principal in increasing community participation can be done through recognition of the community's awareness around the school district, the granting of responsibility to the community in terms of school development, community involvement in various activities, fostering trust, dissemination of excess and strength about the importance of the existence of schools for the future of students, the involvement of Religious leaders or important figures in the area so as to facilitate the implementation of the participation process, and the granting of freedom to the community to provide constructive inputs for the school (Ayman, Kaya, \& Kuruç, 2020). In the involvement of the community must use good techniques or that do not harm the other party and benefit one party only, this technique is used taking into account the existence of Religion, culture and habits of the community in the school area (Garcia, Abrego, \& Jauregui, 2019), namely by providing understanding to religious leaders or important from the region in question so as to facilitate the procurement of participation activities and the collection of inputs for the creation of educational programs (Harsoyo et al., 2019).

Not only build cooperation with external parties of the school, but the principal is also a role model in this independency learning policy. Indirectly, the principal makes a large and strong network to support his leadership, by making himself a role model for internal and external residents of the school. The Principal shows determination in achieving the goal of taking full responsibility for his actions and shows high confidence in the vision of the school (Yang et al., 2015). The school principal acts as a role model in the policy of learning independency, as well as helps build cooperation with related partners. The managerial role of the principal more specifically on social competence is required in several aspects such as (Soebiantoro, 2014), (1) skilled in working with others, (2) being able to participate in social activities, and (3) having social sensitivity. In addition, to achieve the educational objectives a principal must prepare educational programs related to social activities (Berkes \& Ross, 2013; de Morais \& Rapsová, 2019). Social activities will later form the school's self-expression in carrying out the programs and activities that have been prepared (Bedell, Coster, Law, Liljenquist, Kao, Teplicky, ... \& Khetani, 2013; Saidun, Tahir, \& Musah, 2015). With this social activity, the school will have more appeal to the community, especially in participating actively in supporting the learning independency policy in schools.

Based on the findings of the principal's managerial activities continue to run by utilizing existing communication technology. Where it is done by the principal to ensure that school activities continue to run well even though it is done remotely because it limits face-to-face activities during the Covid 19 virus pandemic as it is today (Brammer \& Clark, 2020; Diamond, 2020; Jäppinen, Leclerc, \& Tubin, 2016). Of course, with this condition, the principal needs to make creative efforts in accordance with the era of industrial revolution 4.0 based on the sophistication of information and communication technology as it is now as a form of the principal's commitment in ensuring the entire school program continues to run effectively and efficiently by involving the participation of the community (Harris \& Jones, 2020). With good collaboration from all stakeholders in the field of education, all kinds of obstacles faced in the implementation of independency learning policies especially during the Covid 19 pandemic can be minimized, in fulfilling the responsibility of schools to provide quality education services (Fisher, Languilaire, Lawthom, Nieuwenhuis, Petts, Runswick-Cole, \& Yerkes, 2020; Harris, 2020; Schneider \& Council, 2020).

\section{Forms of Community Participation in Facilitating Learning Independency in Schools}

Based on the results of research on the types of participation received in the three regions, can be grouped into two types of participation, namely active and passive participation (Kahane, Loptson, Herriman, \& Hardy, 2013). Passive 
participation is in the form of support in the form of attitudes, behaviors, and actions that help the implementation of educational programs by the community, while active participation is directly involved in each activity organized. While the form of community participation in the form of material and non-material. In this study, the form of participation given adjusted the uniqueness and peculiarities of each region. In Malang City, East Java, the form of community participation in facilitating independent learning is carried out by several agencies such as universities. In building community participation with universities, schools empower apprentices as classroom teachers, then review the curriculum with courses that suit the subjects and empower specific departments within the universities to innovate learning media for learners. Next, there is a partner school which means that the school builds cooperation with other schools. In this case, the teacher from the partner school will be the resource person or instructor at the time of the ceremony. The next community participation by empowering BNN or the National Narcotics Agency, the school does so that students avoid illegal drugs, because in this era of free association occurs, then build cooperation with the Bank, so that students will hone soft skills in the form of saving and queuing in an orderly manner when going to save. Public health office, by building cooperation with this office, the school expects students to be able to instill a healthy lifestyle. Enviromental services and cleanliness office, students are given directions on how to maintain the environment, this is done so that students can keep the environment comfortable. Learning methods also empower non-governmental organizations UMMI. The location of the school is quite strategic with the presence of industries, not closing the possibility of schools in learning also utilizing the home industry around the school. The school also cooperates with the Faculty of Health, Universitas Brawijaya, this is done for the treatment and dental examination of students, and if there are apprentices will be allocated in the school health unit (UKS).

The findings in the Bondowoso regency of East Java related forms of public participation in facilitating the learning of independence in the form of a role of some institutions such as the local village to examine the flicks in the school bath. Furthermore, to overcome juvenile delinquency, the police participated by providing counseling routinely at the beginning of the semester. Not forgetting also by building the discipline of learners, the Sub-District Military Command or "Koramil" also participate in providing materials. The principal also built a partnership with industry around the school such as home industry making "tape" derived from cassava, then with the Tutoring Institute and banks. There is also an honesty canteen in the school, this is to instill honesty and discipline from the learners. Parents contribute voluntarily, looking at the different economic background conditions of parents so that the school does not force parents to help in material form. Parents also provide assistance in the form of services, so that there is reciprocity between the school and the parents. There are outbond teachers and tourism learners, this is done once a year. There is a sms gateway that conveys that there are activities in school, so that students will not be able to go home to school and parents know the activities of children in school.

The findings in Tana Tidung Regency, North Kalimantan, related forms of public participation in facilitating the learning of independence in the form of a role of some institutions such as universities, namely Universitas Negeri Malang (UM) and Universitas Borneo. Parents facilitate free water transportation for helping student acces to school. This is unique because the geographical location of the school in Tana Tidung Regency of North Kalimantan is separated by mahakam river, so to go to school there are some students have to cross the river. Therefore, parents who have voluntary water transportation give free offers to other students. Not only in facilitating water transportation, but the active role of parents in literacy activities is also apparent. This can be seen when the child is studying at home, the parents will write down the activities on the Student Activity Sheet (LAS). In LAS parents also provide guidance on literacy activities at home. Education Office provide programs related to school development. For junior high school there are dormitories, so that caregivers and ustadz in the dormitory are involved in improving the quality of learning independency. The Tana Tidung Regency of North Kalimantan also has mines, so this excellent school provides village development programs to schools near 
the mine, so that educators remain evenly distributed. Religious leaders around the school also contribute by becoming religious teachers in schools

Community participation itself is decentralized school governance, so many schools take advantage of this community's participation (Ginsburg, Haugen, Lokong, \& Ong'uti, 2017; Talò, Mannarini, \& Rochira, 2014). Related to the decision of minister of education and culture of the Republic of Indonesia aboout independency learning, for the increasing of community participation, creative efforts from the principal are needed to increase community participation. Schools need good partners from the government sector, parents, industry businesses and local community stakeholders (Gali \& Schechter, 2020; Ng \& Lee, 2015; Patrikakou, 2016). Various research results show that community participation is one of the important factors in improving the quality of schools, especially in the context of facilitating the independency learning in schools (Grace \& Harrington, 2015; Harris, Day, Hadfield, Hopkins, Hargreaves, \& Chapman, 2013; Shaked, 2016).

To get a clear picture related to community participation there are various ways, one of which is by studying the previous school documents, so that from here we can correct the mistakes that existed before (Badran \& Toprak, 2020). Based on the exposure of the results of the above research, there are several cooperations formed in the implementation of learning independency by empowering the role of community fiber. As the results of previous research stated that a community will also pay attention to its concern for the school (Dove, Zorotovich, \& Gregg, 2018). That way the mobility of the school's relationship with the community will be easily formed.

\section{CONCLUSION}

Good collaboration from all stakeholders in the field of education in the implementation of learning independency policies especially during the Covid 19 pandemic is very important to do. The principal's efforts in increasing the participation of the community through cooperation with several related parties. Such parties include universities, partner schools, National Narcotics Agency (BNN), banks, local government, army, police, public health office, enviromental services and cleanliness office, alumni, parents, non-government organizations, stakeholders around the school, and industry around the school. Further, some school activities related to independency learning are supported by the participation of the community, namely parents and stakeholder community. Form of support in the form of materials and services. The principal as a role model in the policy of independency learning, as well as to build cooperation with related partners. In this case the principal acts as a role model by participating in activities held in the classroom.

\section{ACKNOWLEDGEMENT}

We thank the Chairman Research and Community Service Institute Universitas Negeri Malang (LP2M UM) as well as the principal, parents, school committee in Tana Tidung Regency of North Kalimantan, Bondowoso Regency of East Java, and Malang City of East Java, and all parties involved in the FGD Meeting and have participated in this research to share ideas during this research.

\section{REFERENCES}

Aas, M., \& Paulsen, J. M. (2019). National Strategy for supporting school principal's instructional leadership: A Scandinavian approach. Journal of Educational Administration, 57(5), 540-553. https:// doi.org/10.1108/JEA-09-2018-0168.

Abidah, A., Hidaayatullaah, H. N., Simamora, R. M., Fehabutar, D., \& Mutakinati, L. (2020). The impact of Covid-19 to Indonesian education and its relation to the philosophy of "merdeka belajar". Studies in Philosophy of Science and Education, 1(1), 38-49. https://doi.org/10.46627/ sipose.v1i1.9.

Akkary, R. K. (2013). The role and role context of the Lebanese school principal: Toward a culturally grounded understanding of the principalship. Educational Management Administration \& Leadership, 42(5), 718-742. https://doi. org/10.1177/1741143213510503.

Ayman, U., Kaya, A. K., \& Kuruç, U. K. (2020). The impact of digital communication and 
PR Models on the sustainability of higher education during crises. Sustainability, 12(20), 1-15. https://doi.org/doi:10.3390/ $\underline{\text { su12208295. }}$.

Badran, A., \& Toprak, M. (2020). Sustainability of education reforms: An investigation into the professional development component of USAID/egypt Education Reform Program (ERP, 2004-2009). Education Policy Analysis Archives, 28(129), 1-34. https://doi.org/10.14507/epaa.28.5010.

Barnett, K., \& McCormick, J. (2012). Leadership and team dynamics in senior executive leadership teams. Educational Management Administration \& Leadership, 40(6), 653-671. https://doi. org/10.1177/1741143212456909.

Baro'ah, S. (2020). Kebijakan merdeka belajar sebagai strategi peningkatan mutu pendidikan. [Independent learning policy as a strategy to improve the quality of education]. Tawadhu, 4(1), 1063-1073. https://ejournal.iaiig.ac.id/index.php/ TWD/article/view/225.

Bedell, G., Coster, W., Law, M., Liljenquist, K., Kao, Y. C., Teplicky, R., ... \& Khetani, M. A. (2013). Community participation, supports, and barriers of school-age children with and without disabilities. Archives of Physical Medicine and Rehabilitation, 94(2), 315-323. https:// doi.org/10.1016/j.apmr.2012.09.024.

Berkes, F., \& Ross, H. (2013). Community resilience: Toward an integrated approach. Society and Natural Resources, 26(1), 5-20. https://doi.org/10.1080/08941920.2 $\underline{012.736605}$.

Blechman, F., Davidson, C., \& Kelly, W. (2017). Community participation. In W.E. Kelly, B. Luke, \& R. N. Wright (Eds.). Engineering for sustainable communities: Principles and practices. Reston, VA: American Society of Civil Engineerspp. 179-200. https://doi.org/10.1061/9780784414811. ch13.

Brammer, S., \& Clark, T. (2020). Covid-19 and management education: Reflections on challenges, opportunities, and potential futures. British Journal of Management, 31(3), 453-456. https://doi. org/10.1111/1467-8551.12425.

Brinia, V., Zimianiti, L., \& Panagiotopoulos, K. (2014). The role of the principal's emotional intelligence in primary education leadership. Educational Management Administration \& Leadership, 42(4 Suppl), 28-44. https:// doi.org/10.1177/1741143213513183.

Chan, C. W. (2014). The leadership styles of Hongkong kindergarten principals in a context of managerial change. Educational Management Administration and Leadership, 42(1), 30-39. https://doi. org/10.1177/1741143213499263.

Çoruk, A. (2018). School principals' opinions about public relations practices on schools. International Journal of Progressive Education, 14(2), 136-147. https://doi. org/10.29329/ijpe.2018.139.10.

de Morais, M. M., \& Rapsová, L. (2019). Psychological bases of developing social competences of seniors with disability. Australian Journal of Adult Learning, 59(2), 289-292. https://ajal. net.au/downloads/psychological-basesof-developing-social-competences-ofseniors-with-disability/.

Diamond, C. (2020). School leadership and Covid-19: A chance to create a better education system in england for the longterm. https://www.birmingham.ac.uk/ research/perspective/school-leadershipcovid-19.aspx.

Dinham, S., \& Crowther, F. (2011). Sustainable school capacity building-one step back, two steps forward? Journal of Educational Administration, 49(6), 616-623. https:// doi.org/10.1108/09578231111186926.

Dove, M. K., Zorotovich, J., \& Gregg, K. (2018). School community connectedness and family participation at school. World Journal of Education, 8(1), 49-57. https:// doi.org/10.5430/wje.v8n1p49. 
Falahah, F., \& Rosmala, D. (2012). Study of social networking usage in higher education environment. Procedia - Social and Behavioral Sciences, 67, 156-166. https:// doi.org/10.1016/j.sbspro.2012.11.316.

Fisher, J., Languilaire, J. C., Lawthom, R., Nieuwenhuis, R., Petts, R. J., RunswickCole, K., \& Yerkes, M. A. (2020). Community, work, and family in times of Covid-19. Community, Work and Family, 23(3), 247-252. https://doi.org/10.1080/1 $\underline{3668803.2020 .1756568 .}$.

Gali, Y., \& Schechter, C. (2020). NGO involvement in education policy: Principals' voices. International Journal of Educational Management, 34(10), 1509-1525. https://doi.org/10.1108/ IJEM-02-2020-0115.

Garcia, A., Abrego, J., \& Jauregui, J. (2019). Technologies frequently used by elementary principals. Universal Journal of Educational Research, 7(1), 95-105. https://doi.org/10.13189/ ujer.2019.070113.

Ginsburg, M., Haugen, V., Lokong, F., \& Ong'uti, S. (2017). Promoting community participation in improving education in South Sudan. African Educational Research Journal, 5(4), 221-239. http:// www.netjournals.org/z_AERJ_17_052. html.

Grace, R. A., \& Harrington, S. Y. (2015). Our children, our schools: Seeking solutions for improving the climate in urban public schools. Alabama Journal of Educational Leadership, 2(1), 1-14. https://files.eric. ed.gov/fulltext/EJ1097524.pdf.

Harris, A. (2020). COVID-19-School leadership in crisis? Journal of Professional Capital and Community, 5(3/4), 321-326. https:// doi.org/10.1108/JPCC-06-2020-0045.

Harris, A., Day, C., Hadfield, M., Hopkins, D., Hargreaves, A., \& Chapman, C. (2013). Effective leadership for school improvement. London: Routledge. https:// doi.org/10.4324/9780203754849.
Harris, A., \& Jones, M. (2020). COVID 19school leadership in disruptive times. School Leadership and Management, 40(4), 243-247. https://doi.org/10.1080/1 3632434.2020.1811479.

Harsoyo, Y., Astuti, C, W. R., \& Rahayu, C. W. E. (2019). Competency and values of local wisdom of high school principals. Cakrawala Pendidikan, 38(3), 565-577. https://doi.org/10.21831/cp.v38i3.20593.

Hendri, N. (2020). Merdeka belajar: Antara retorika dan aplikasi. [Independent learning: Between rhetoric and application]. E-Tech, 8(1), 1-9. http:// ejournal.unp.ac.id/index.php/e-tech/ article/view/107288.

Hutton, D. M. (2017). Leadership performance model for the effective school principal. Journal of School Leadership, 27(4), 553-580. https://doi. org/10.1177/105268461702700404.

Intxausti, N., Joaristi, L., \& Lizasoain, L. (2016). Educational leadership as best practice in highly effective schools in the autonomous region of the Basque County (Spain). Educational Management Administration and Leadership, 44(3), 397-419. https:// doi.org/10.1177/1741143214558570.

Jahari, J. (2020). Preparing teachers in the era of "independence learning" in Indonesia. International Journal of Psychosocial Rehabilitation, 24(7), 3990-3998. https://www.psychosocial.com/article/ PR270395/15682/.

Jäppinen, A. K., Leclerc, M., \& Tubin, D. (2016). Collaborativeness as the core of professional learning communities beyond culture and context: Evidence from Canada, Finland, and Israel. School Effectiveness and School Improvement, 27(3), 315-332. https://doi.org/10.1080/0 $\underline{9243453.2015 .1067235}$.

Juharyanto, J., Sultoni, S., Arifin, I., Bafadal, I., Nurabadi, A., \& Hardika, H. (2020). "Gethok Tular" as the leadership strategy of school principals to strengthen multi-stakeholder forum role 
in improving the quality of one-roof schools in remote areas in Indonesia. SAGE Open, 10(2), 1-12. https://doi. org/10.1177/2158244020924374.

Kahane, D., Loptson, K., Herriman, J., \& Hardy, M. (2013). Stakeholder and citizen roles in public deliberation. Journal of Public Deliberative Democracy, 9(2), 1-35. https://doi.org/10.16997/jdd.164.

Kin, T. M., Kareem, O. A., Nordin, M. S., \& Bing, K. W. (2017). Principal change leadership competencies and teacher attitudes toward change: The mediating effects of teacher change beliefs. International Journal of Leadership in Education, 21(4), 427-446. https://doi.org/10.1080/13603124.2016.1 272719.

Koc, K., \& Turan, M. B. (2018). The impact of cultural intelligence on social skills among university students. Journal of Education and Learning, 7(6), 241-249. https://doi. org/10.5539/jel.v7n6p241.

Lindqvist, H. M., \& Pettersson, F. (2019). Digitalization and school leadership: On the complexity of leading for digitalization in school. International Journal of Information and Learning Technology, 36(3), 218-230. https://doi.org/10.1108/ IJILT-11-2018-0126.

Lunenburg, F. C. (2010). The principal as instructional leader. National Forum of Educational Administration and Supervision Journal, 27(4), 1-7. http:// www.nationalforum.com/Journals/ NFEASJ/NFEASJ.htm.

Lunenburg, F. C. (2011). Understanding organizational culture: A key leadership asset. National Forum of Educational Administration and Supervision Journal, 29(4), 1-12. http://www.nationalforum. com/Journals/NFEASJ/NFEASJ.htm.

Malakolunthu, S., McBeath, J., \& Swaffield, S. (2014). Improving the quality of teaching and learning through leadership for learning: Changing scenarios in basic schools of Ghana. Educational Management Administration \&
Leadership, 42(5), 701-717. https://doi. org/10.1177/1741143213510510.

Mapp, K. L., \& Kuttner, P. J. (2013). Partners in education: A dual capacity-building framework for family-school partnerships parents. Austin, Texas: Sedl. https://sedl. org/pubs/framework/.

McEwan, P. J. (2015). Improving learning in primary schools of developing countries: A meta-analysis of randomized experiments. Review of Educational Research, 85(3), 353-394. https://doi. org/10.3102/0034654314553127.

Mulyani, H., Meirawan, D., \& Rahmadani, A. (2020). Increasing school effectiveness through principals' leadership and teachers' teaching performance, is it possible? Cakrawala Pendidikan, 39(2), 279-292. https://doi.org/10.21831/ cp.v39i2.28864.

Ng, S. W., \& Lee, T. H. T. (2015). How parents were involved in a special school in Hong Kong. International Journal of Educatioal Management, 29(4), 420-430. https://doi. org/10.1108/IJEM-07-2014-0095.

Patrikakou, E. N. (2016). Parent involvement, technology, and media: Now what? School Community Journal, 26(2), 9-24. https://www.schoolcommunitynetwork. org/SCJ.aspx.

Rahabav, P. (2016). The effectiveness of academic supervision for teachers. Journal of Education and Practice, 7(9), 47-55. https://www.iiste.org/Journals/ index.php/JEP/article/view/29620.

Rivai, V., \& Murni, S. (2009). Education management. Jakarta: Rajawali Pers.

Saidun, R., Tahir, L. M., \& Musah, M. B. (2015). Problems faced by novice principals in Malaysia: An exploration study. Mediterranean Journal of Social Sciences, 6(4), 562-569. https://doi.org/10.5901/ mjss.2015.v6n4s3p562.

Sari, H., \& Gökdağ, H. (2017). An analysis of difficulties of children with stuttering 
enrolled in Turkish primary inclusive classes who encounter in academic and social activities: From their perspectives. Journal of Education and Practice, 8(2), 31-43. https://www.iiste.org/Journals/ index.php/JEP/article/view/35071.

Schneider, S. L., \& Council, M. L. (2020). Distance learning in the era of COVID-19. Archives of Dermatological Research, 1-2. https://doi.org/10.1007/s00403-02002088-9.

Shaked, H. (2016). Parental participation fees in school expenses in Israel. International Journal of Educational Management, 30(1), 63-75. https://doi.org/10.1108/ IJEM-09-2014-0127.

Soebiantoro, S. (2014). Kompetensi kepala sekolah dalam pelaksanaan MPBS di SMK pemuda Blitar. [The competence of school principals in implementing MPBS at Blitar youth vocational high school]. Cendekia, 8(2), 121-136. https://doi. org/10.30957/cendekia.v8i2.58.

Sofoluwe, A. O., \& Akinsolu, A. O. (2015). Community Participation in Quality Assurance (CPQA): A catalyst in enhancing quality basic education service delivery in Nigeria. Journal of Education and Practice, 6(7), 12-19. https://www. iiste.org/Journals/index.php/JEP/article/ view/20667.

Šteh, B., \& Kalin, J. (2011). Building partner cooperation between teachers and parents. Center for Educational Policy Studies Journal, 1(4), 81-101. https://www.cepsj. si/index.php/cepsj/article/view/407.

Talò, C., Mannarini, T., \& Rochira, A. (2014). Sense of community and community participation: A meta-analytic review. Social Indicators Research, 117(1), 1-28. https://doi.org/10.1007/s11205-013$\underline{0347-2}$.

Ulfatin, N., Mustiningsih, Sumarsono, R. B., \& Yunus, J. N. (2020). Schoolbased management in marginal areas: Satisfying the political context and student needs. Management in Education, 20(10), 1-11. https://doi. org/10.1177/0892020620959739.

Wiyono, B. B. (2018). The effect of self-evaluation on the principals' transformational leadership, teachers' work motivation, teamwork effectiveness, and school improvement. International Journal of Leadership in Education, 21(6), 705-725. https://doi.org/10.1080/1 3603124.2017 .1318960 .

Yamin, M., \& Syahrir, S. (2020). Pembangunan pendidikan Merdeka Belajar (Telaah metode pembelajaran). [Development of independent learning education (Assessing Learning Methods)]. Jurnal Ilmiah Mandala Education, 6(1), 126-136. https://doi.org/10.36312/jime.v6i1.1121.

Yang, F., Chen, X., \& Wang, L. (2015). Shynesssensitivity and social, school, and psychological adjustment in urban Chinese children: A four-wave longitudinal study. Child Development, 86(6), 1848-1864. https://doi.org/10.1111/cdev.12414. 